\title{
Environmental management for the control of Triatoma dimidiata (Latreille, 1811), (Hemiptera: Reduviidae) in Costa Rica: a pilot project
}

\author{
Rodrigo Zeledón/+ , Julio C Rojas*
}

Laboratorio de Zoonosis, Escuela de Medicina Veterinaria, Universidad Nacional, Apartado Postal 1466-2050 San José,
Costa Rica * Unidad de Epidemiología, Escuela de Medicina Veterinaria, Universidad Nacional, Heredia, Costa Rica

An ecological control method, using environmental management operations, based on biological and behavioral characteristics of Triatoma dimidiata (Latreille, 1811), was implemented as a pilot project in an area of Costa Rica where the bug is prevalent.

The sample was represented by 20 houses with peridomestic colonies (two also had indoor infestation), divided in two equivalent groups of 10 each. In one group we intervened the houses, i.e. all objects or materials that were serving as artificial ecotopes for the bugs were removed, and the second group was used as control houses.

After a year of periodic follow up, it became evident that in those houses with a modified environment the number of insects had decreased notoriously even after the first visits and this was more evident after a period of 12.5 to 13.5 months in which no insects were detected in eight of the houses. It also became clear that in this group of houses, recolonization by wild bugs from the surrounding areas, became more difficult, probably due to the absence of protection from bug predators. In the control houses, with the exception of three in which the inhabitants decided to intervene on their own, and another house with a peculiar situation, the insect populations remained the same or even showed a tendency to increase, as confirmed at the end of the experiment.

We believe that the method is feasible, low costing and non contaminating. It could be used successfully in other places where T. dimidiata is common and also in countries where other species colonize peridomestic areas of homes. Environmental management of this kind should seek the participation of the members of the communities, in order to make it a more permanent control measure.

Key words: environmental management - Triatoma dimidiata - pilot project - Costa Rica

In some areas of Central America Triatoma dimidiata is either the only vector or the second most important vector of Chagas disease (Ponce 1996, Zeledón 1996). It is a native species that frequently colonizes human dwellings and is well represented in sylvatic ecotopes under different ecological conditions (Zeledón et al. 2001, Monroy et al. 2003).

The Central American Initiative, launched in 1997 for the control of vectorial and transfusional transmission of Chagas disease, has among its objectives "the reduction of the infestation and colonization indexes of $T$. $d i$ midiata..." (WHO 2002). A workshop held in El Salvador in March of 2002, which was sponsored by the Pan American Health Organization (OPS 2002), specifically addressed the control of $T$. dimidiata in Central America, and made, among others, this recommendation: "to evaluate the effectiveness of different methods for the control of $T$. dimidiata at the domiciliary and peridomiciliary levels".

Financial support: in the first phase by the Instituto Costarricense de Investigación y Enseñanza en Nutrición y Salud and in the final phase by the ChagaSpace project, under a contract between EARTH University and the National University of Costa Rica.

Corresponding author: rodrigozeledon@ice.co.cr

Received 27 December 2005

Accepted 3 May 2006
To date, the most feasible mechanism to interrupt vectorial transmission when intradomiciliary colonies of any vector of Chagas disease are found, is chemical control (WHO 2002). Nevertheless, with species such as $T$. dimidiata, which also colonizes peridomiciliary areas, the problem of control becomes cumbersome. Bos (1988) analyzed this situation from a theoretical standpoint, and concluded that environmental management (environmental modifications) is the correct approach for the control of peridomestic triatomines.

Based on these premises, and on the ecological and ethological knowledge we have accumulated over the years on T. dimidiata (Zeledón 1981), we decided to carry out a pilot study in an area of Costa Rica where the bug is prevalent. We call "ecological control" those environmental management operations that are used here to eliminate domestic or peridomestic colonies of $T$. dimidiata, in contrast to physical control, which is focused on permanent structures of the house (physical modifications), as defined by others (WHO 2002).

We are proposing here not only to eliminate the manmade ecotopes commonly colonized by $T$. dimidiata, but also to destroy the nests or habitats of wild or synanthropic animals (rodents, marsupials) that provide a blood source for the insects in the peridomiciliary areas. By this method we are altering the entire biocenoses produced by these artificial ecotopes inside, beneath or around the household in order to reduce or avoid the man-insect contact in a sustainable way with the cooperation and under- 
standing of the entire community involved.

By using environmental modifications as a basic tool we hope to demonstrate that we could achieve the elimination of $T$. dimidiata by this method or at least to produce a marked decrease in its colonies from infested households and also make life difficult for adventitious visiting bugs that attempt to recolonize the place.

\section{MATERIALS AND METHODS}

Study area - The project was carried out in a sector called "Barrio Pilar", in the district Vuelta de Jorco, Aserrí county, San José province. It is located $20 \mathrm{~km}$ southwest of San José, the capital of Costa Rica, 09 $47^{\prime} 52^{\prime \prime} \mathrm{N}$ and $84^{\circ}$ $07 ' 55^{\prime}$ 'W, at an altitude of $1120 \mathrm{~m}$. The mean annual rainfall recorded at a station located $5 \mathrm{~km}$ from the study area was $1745.5 \mathrm{~mm}$ for 2002. "Barrio Pilar" begins opposite to the local primary school, on one side of the main road that connects San José with San Ignacio de Acosta. The area is part of the central highlands of the country and its topography is irregular and uneven. There is a marked slope from the south to the northwest down to the "Rio Jorco" which marks the end of "Barrio Pilar" (Fig. 1). The longest distance between house $1 \mathrm{~A}$ and house 48, was $840 \mathrm{~m}$. There are 180 houses in the place, which are surrounded by coffee plantations, and the coffee manufacturing process is managed by a local cooperative.

In a previous survey of 50 houses in the area performed in August-September of 2001, as part of a wider study in three other regions of the country to evaluate different parameters related to the prevalence of $T$. dimidiata (Zeledón et al. unpublished data), we were able to determine an infestation index of 44\% (22 infested houses) in "Barrio Pilar". Due to this fact, and to the proximity of the place to our headquarters, we decided to choose this place for a pilot control project of $T$. dimidiata.
Sample - In the year prior to our second survey, we visited the local school and talked to the students about the importance of the control of the insect and about the consequences of Chagas disease, which is transmitted by $T$. dimidiata. After showing them some specimens of the insect the great majority recognized it and many expressed having seen the bug in their own homes. We also approached the physician in charge of the local health clinic and, as in the case of the Director and teachers of the school, obtained full cooperation with our task. One of the community leaders, who deals with pet and other animal care in the village, was instrumental in "opening doors" to all houses that we visited.

The 22 houses previously considered as infested were searched again a year after the first survey (October 2002 to November 2003), and 12 of them were selected for the control experiment and 10 were excluded for various reasons. In four of these, the inhabitants had made physical changes, eliminating the insects temporarily; in two houses the owners had recently sprayed insecticide; one house was demolished; another house was accidentally burned; and, in the last two houses, which previously had a few insects, we were unable to find them again.

The search for eight new infested houses, in order to complete the 20 needed, was performed in a group of households not included in the 50 used the first time. Once selected, the 20 infested households were divided in two equivalent groups of 10 each in order to intervene in the houses of one group (case-houses), leaving the others as control-houses.

Due to the irregularities of the terrain, many houses in the area are built on stilts leaving spaces underneath which are used as storage areas, facilitating the formation of bug colonies. In some cases the owners had even built store rooms or cellars in these spaces.

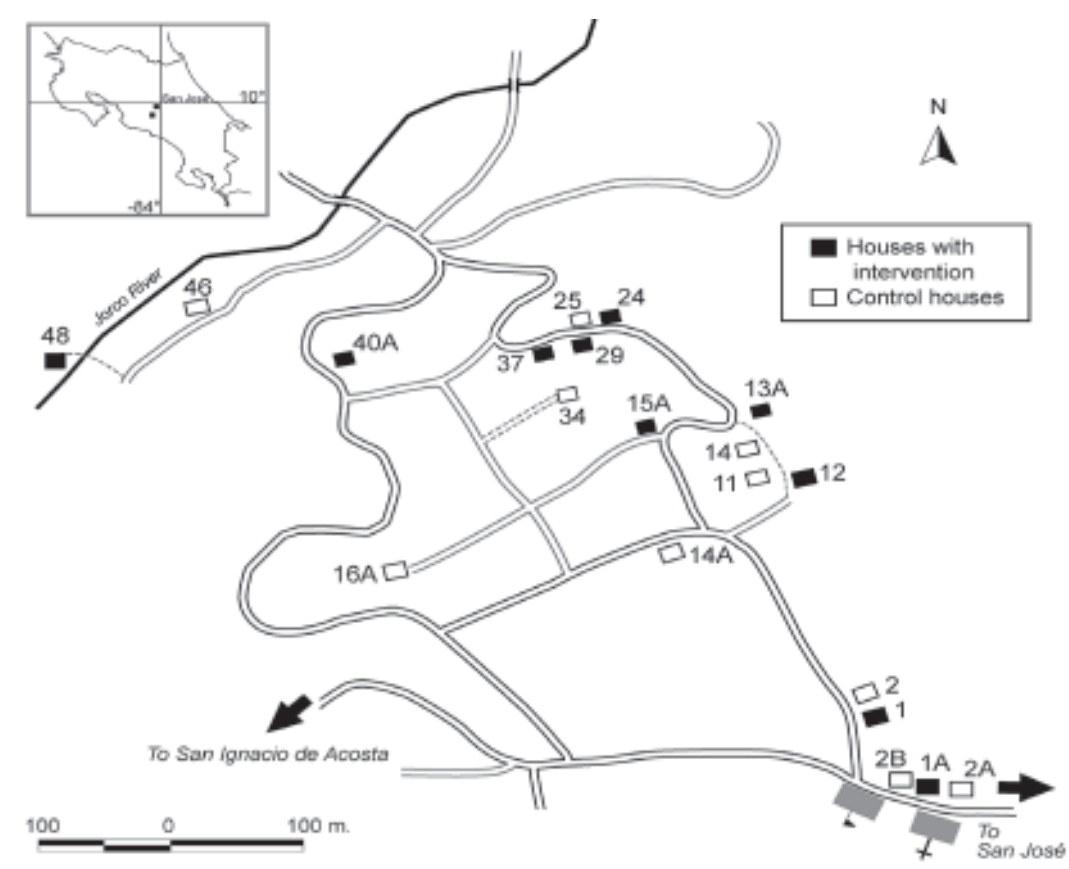

Fig. 1: map of Barrio Pilar showing the distribution of the 20 houses used for the ecological control pilot project of Triatoma dimidiata. 
The houses were paired by taking into consideration several parameters in order to match them in two similar groups, such as type of construction or structural characteristics, number and location of insects found, presence of firewood or wood piles, and even distribution along the areas where the houses were located (Fig. 1).

All insect searches and environmental changes were done by four well trained senior university students, following an established protocol for the purpose. We used the man/h method with at least two team members searching simultaneously with the help of forceps and a flash light.

The mean time periods used in the search for the insects was $0.5 \mathrm{man} / \mathrm{h}$ for the indoors and $1 \mathrm{man} / \mathrm{h}$ for the outdoors for the first 9-9.5 months after the control interventions and $0.5 \mathrm{man} / \mathrm{h}$ and $2 \mathrm{man} / \mathrm{h}$ respectively, for the last search at 12.5-13.5 months.

Environmental management - The aim of the modifications at the 10 chosen infested houses was to remove all sorts of disorderly objects or materials, modifying artificial ecotopes that serve as hiding and breeding sites for the insects (Zeledón 1981). For practical purposes we considered as peridomicilary or peridomestic all areas immediately surrounding the houses, and considered as part of the backyard, generally limited by a fence, including the spaces beneath the houses (Fig. 2).

The environmental changes required for implementing ecological control in the 10 chosen houses, required four trained persons working together from 2 to $9 \mathrm{~h}$ with a mean time of $4.5 \mathrm{~h}$ per house.

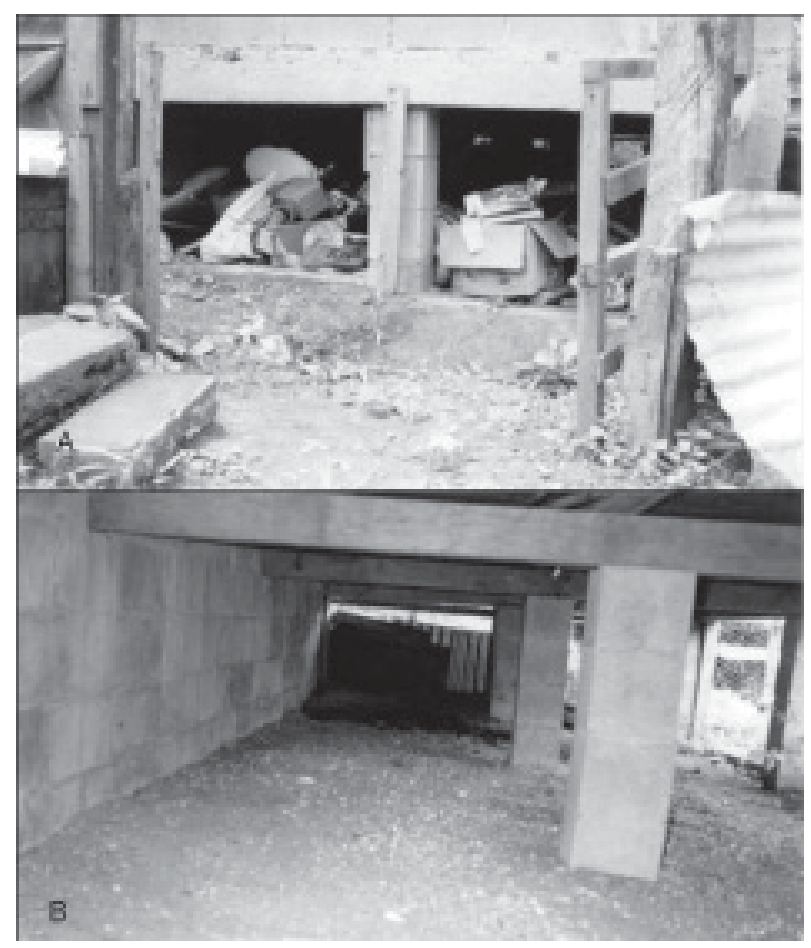

Fig. 2: space beneath house 12. A: before intervention; B: after intervention.
The occupants of the houses in most cases cooperated in the process and once they recognized that many of the stored items were useless, they helped to put them in plastics garbage bags for disposal. In two cases we had to construct simple movable platforms $25 \mathrm{~cm}$ from the floor to relocate some of the goods that had no other place to be moved. In the case of house no. 1, the owner asked us to completely tear down the only store room where the bugs were living, located $2 \mathrm{~m}$ behind the house in the backyard.

At the end of the observation period and in total agreement with the occupants, the control-houses were also modified in the same fashion as the case-houses.

Trypanosoma cruzi infection - All insects were examined for T. cruzi infection by observing a feces drop obtained by pressure to the abdomen, diluting it in saline solutions and observing in a light microscope.

Data analysis - Data processing and analysis were conducted with SPSS for Windows (Release 8.8.SPSS Inc. 1997). Tests for significant differences between means were performed using Student's t-test (Snedecor \& Cochran 1989), and comparisons of two proportions were done to test for the differences among selected variables between intervened and control houses. The proportion of insects (number of insects in a house/total number of insects in the respective group) in both groups of houses was tested by using the two-sample test for binomial proportions.

\section{RESULTS}

In the interior of 11 of the 20 houses, the sanitary conditions were good and in nine they were fair. None of the houses had a dirt floor, which could explain the low rates of indoor colonization by the bugs. The situation was different outdoors where the sanitary conditions of the peridomiciliary areas and of the open spaces beneath the houses were poor in 16 cases and fair only in four. This explains the frequent colonization by the insect in these areas where they find numerous artificial ecotopos suitable for thriving. Nevertheless, when the colonies are under the house the bugs can climb to the rooms through cracks around the baseboard or floor and return to the original place after satisfying their hunger. This was observed in at least one case (house 12) in which a colony of bugs was found in an opossum nest directly beneath a room of a child who was bitten several times without the mother being able to find the responsible insect.

All houses had fire wood and/or wood piles and 13 of them were built on stilts; 14 of the 20 had a store room beneath, close to or at certain distance from the house.

The dog population was only 12 animals belonging to five households and there were 133 chickens distributed in five houses but no bugs were found in the chicken coops. At least nine householders had seen opossums around their homes and these animals were very common in the surrounding coffee plantations. The inhabitants of at least 16 houses had seen adult bugs arriving in the surroundings of their respective houses.

In Tables I and II we show the situation of the two groups of houses in relation to the number of insects 
TABLE I

Degree of infestation by Triatoma dimidiata of the 10 houses in which environmental management was practiced, before and during the intervention and rates of infection of the bugs by Trypanosoma cruzi

\begin{tabular}{|c|c|c|c|c|c|c|}
\hline House & $\begin{array}{l}\text { No. insects } \\
\text { before } \\
\text { intervention }\end{array}$ & $\begin{array}{l}\text { No. insects } \\
\text { during } \\
\text { intervention }\end{array}$ & Location & $\begin{array}{l}\text { No. of adults } \\
\text { (\% of infection) }\end{array}$ & $\begin{array}{l}\text { No. of nymphs } \\
\text { (\% of infection) }\end{array}$ & $\begin{array}{l}\text { Total } \\
\text { No. of insects } \\
\text { (\% of infection) }\end{array}$ \\
\hline 1 & 5 & 20 & Store room & $3(66.7)$ & $22(45.0)$ & $25(12.0)$ \\
\hline $1 \mathrm{~A}$ & 58 & 187 & Under house (wood piles) & $11(100)$ & $234(37.6)$ & $245(40.4)$ \\
\hline 12 & 1 & 9 & Under house & $1(100)$ & $9(22.2)$ & $10(30.0)$ \\
\hline $13 \mathrm{~A}$ & 2 & 7 & Store room & $1(100)$ & $8(0)$ & $9(10.0)$ \\
\hline $15 \mathrm{~A}$ & 15 & 12 & $\begin{array}{l}\text { Under house (wood piles) } \\
\text { Store room }\end{array}$ & $3(66.7)$ & $24(29.2)$ & $27(33.3)$ \\
\hline 24 & 5 & 45 & Store room & $7(71.4)$ & $43(25.6)$ & $50(32.0)$ \\
\hline 29 & 5 & 5 & Store room & $0(0)$ & $10(50.0)$ & $10(50.0)$ \\
\hline 37 & 5 & 72 & Under house (fire wood piles) & $13(15.4)$ & $64(1.6)$ & $77(3.9)$ \\
\hline $40 \mathrm{~A}$ & 5 & 3 & Under house (wood piles) & $0(0)$ & $8(0)$ & $8(0)$ \\
\hline $48^{a}$ & 5 & 27 & Store room & $2(0)$ & $30(33.3)$ & $32(31.3)$ \\
\hline Total & 106 & 387 & & $41(58.5)$ & $452(27.7)$ & $493(30.2)$ \\
\hline
\end{tabular}

$a$ : the only house with intradomiciliary infestation (three nymphs and one adult were found in the dormitory).

TABLE II

Degree of infestation by Triatoma dimidiata of the 10 houses used as controls and rates of infection of the bugs by Trypanosoma cruzi

\begin{tabular}{lclccc}
\hline House & $\begin{array}{c}\text { No. insects } \\
\text { found }\end{array}$ & Location & $\begin{array}{c}\text { No. of adults } \\
\text { (\% of infection) }\end{array}$ & $\begin{array}{c}\text { No. of nymphs } \\
(\% \text { of infection) }\end{array}$ & $\begin{array}{c}\text { Total No. of insects } \\
(\% \text { of infection })\end{array}$ \\
\hline 2 & 1 & Store room & $0(0)$ & $1(0)$ & $1(0)$ \\
$2 \mathrm{~A}$ & 19 & Under house (wood piles) & $0(0)$ & $19(57.9)$ & $19(57.9)$ \\
$2 \mathrm{~B}$ & 4 & Under house (wood piles) & $0(0)$ & $4(0)$ & $4(0)$ \\
$11{ }^{a}$ & 16 & Under house (wood piles) & $0(0)$ & $16(64.3)$ & $16(64.3)$ \\
14 & 10 & Under house & $1(100)$ & $11(33.3)$ & $10(40.0)$ \\
$14 \mathrm{~A}$ & 12 & Fire wood pile (back corridor) & $1(100)$ & $19(31.6)$ & $12(33.3)$ \\
$16 \mathrm{~A}$ & 20 & Wood piles (back yard) & $1(0)$ & $8(0)$ & $20(30.0)$ \\
25 & 8 & Under house & $0(0)$ & $3(0)$ & $8(0)$ \\
34 & 3 & Store room (fire wood) & $0(0)$ & $1(0)$ & $3(0)$ \\
46 & 3 & Under house (wood piles) & $2(50)$ & $91(35.2)$ & $3(3.33)$ \\
\hline Total & 96 & & $5(60)$ & $96(36.5)$ \\
\hline
\end{tabular}

$a$ : the only house with intradomiciliary infestation (two nymphs were found in the dormitory).

found in each, places where they were encountered, and the rates of infection by $T$. cruzi. In the case of the houses where ecological control was practiced we found 106 insects the first time, as compared with 96 for the control houses (time 0 or base line, $\mathrm{p}>0.05$ ), and 387 more were found during the intervention about a month later.

It is evident that all houses had been colonized outdoors and only in two houses, one of each group, was internal colonization observed but there were very few insects indoors, not noticed again in the subsequent searches.

As commonly occurs with this species of bug, the colonies tend to be relatively small with some exceptions such as those found in houses 1A, 24, and 37 after a detailed search.

In Tables III and IV we compare the number of insects that were captured at the beginning and at each interval after the intervention both in the case-houses as well as in the controls-houses.
It became evident that in the houses where the environment had been modified, the population of insects decreased considerably and remained very small in a few of the houses, with a tendency to disappear early in the process. At 9-9.5 months the insects were not found in six of the houses and in three there was only one nymph on each, and in the remaining house (48) there were four adult bugs and one first instar nymph, indicating a recolonization by wild adults from the surrounding secondary forest that grows in the Jorco River area. This was one of the cases where we rearranged the goods, as requested by the owners, in shelves above the ground in the store room. After 12.5-13.5 months of the ecological control operation, practically all houses were free of insects, including the one with the highest population (1A), except house 24 where two adults and one large nymph had come to the same store room and house 48 where a second instar nymph was found, which probably resulted from the adults that were observed there previously. In the former 
TABLE III

Degree of infestation by Triatoma dimidiata of the 10 houses in which environmental modifications were practiced (ecological control) at the initial and at the end of the process

\begin{tabular}{|c|c|c|c|c|c|}
\hline House & $\begin{array}{l}\text { Initial No. } \\
\text { of insects }{ }^{a}\end{array}$ & $\begin{array}{l}\text { No. of insects at } \\
\text { first visit } b\end{array}$ & $\begin{array}{l}\text { No. of insect at } \\
\text { second visit } c\end{array}$ & $\begin{array}{l}\text { No. of insect at } \\
\text { third visit } d\end{array}$ & $\begin{array}{l}\text { No. of insect at } \\
\text { fourth visit } e\end{array}$ \\
\hline 1 & 25 & 0 & 0 & $1^{f}$ & 0 \\
\hline $1 \mathrm{~A}$ & 245 & ND & 5 & 0 & 0 \\
\hline 12 & 10 & 0 & 0 & 0 & $0^{h}$ \\
\hline $13 \mathrm{~A}$ & 9 & ND & 0 & $1^{f}$ & 0 \\
\hline $15 \mathrm{~A}$ & 27 & 3 & 0 & $1^{f}$ & 0 \\
\hline 24 & 50 & 2 & 3 & 0 & $3^{i}$ \\
\hline 29 & 10 & 0 & 1 & 0 & 0 \\
\hline 37 & 77 & 0 & 0 & 0 & 0 \\
\hline $40 \mathrm{~A}$ & 8 & 1 & 0 & 0 & 0 \\
\hline 48 & 32 & ND & 6 & $5^{g}$ & $1^{j}$ \\
\hline Total & 493 & 6 & 15 & 8 & 4 \\
\hline
\end{tabular}

ND: not done; $a$ : before and after the intervention; $b$ : 15-20 days after the process; $c$ : 42-63days after the process; $d$ : 9-10 months after the process; $e: 12.5-13$ months after the process; $f$ : two 5 th instar nymphs and one 4th instar nymph; $g$ : four adults and one 1 st instar nymph; $h$ : adult male in neighbor house; $i$ : two adults and one 5 th instar nymph; $j$ : one 2 nd instar nymph.

TABLE IV

Degree of infestation by Triatoma dimidiata of the 10 houses used as controls at the initial moment and at the end of the process

\begin{tabular}{|c|c|c|c|c|c|}
\hline House & $\begin{array}{l}\text { Initial No. } \\
\text { of insects }\end{array}$ & $\begin{array}{l}\text { No. of insects } \\
\text { at first visit } a\end{array}$ & $\begin{array}{l}\text { No. of insect } \\
\text { at second visit } b\end{array}$ & $\begin{array}{l}\text { No. of insect } \\
\text { at third visit } c\end{array}$ & $\begin{array}{l}\text { No. of insect } \\
\text { at fourth visit }\end{array}$ \\
\hline 2 & 1 & 1 & 0 & 0 & 0 \\
\hline $2 \mathrm{~A}$ & 19 & ND & 2 & 11 & 8 \\
\hline $2 \mathrm{~B}$ & 4 & ND & 2 & 3 & 20 \\
\hline 11 & 16 & 7 & 3 & 3 & 9 \\
\hline 14 & 10 & 1 & $0^{e}$ & 0 & 0 \\
\hline $14 \mathrm{~A}$ & 12 & 8 & 2 & $0^{e}$ & 0 \\
\hline $16 \mathrm{~A}$ & 20 & 1 & 13 & $5^{f}$ & 71 \\
\hline 25 & 8 & 5 & $0^{e}$ & 0 & 0 \\
\hline 34 & 3 & 3 & 1 & 2 & 16 \\
\hline 46 & 3 & 1 & 2 & 2 & 6 \\
\hline Total & 96 & 27 & 25 & 26 & 130 \\
\hline
\end{tabular}

ND: not done; $a$ : 28-40 days after; $b: 34-78$ days after; $c$ : 9-9.5 months after; $d$ : 12.5-13.5 months after; $e$ : the inhabitants decided to modify the environment; $f$ : the inhabitants captured 12 additional insects.

case (house 24), the store room was partially open on one side and was located very close to a group of trees where opossum nests were found. A search in the middle of the coffee plantation behind the house, revealed two colonies of bugs in two old sheds, one with four adults and four nymphs and the other with seven nymphs; these sheds were used to store wood and other objects and were located $200 \mathrm{~m}$ from house 24 .

In the case of the 10 control houses, it can be observed that seven maintained the infestation and in three houses the insects were not found during the second inspection. The cellar in house 2 , which began with a very low population of bugs, was located only $12 \mathrm{~m}$ from the store room which we had demolished in house 1. During the demolition, we found a colony of 20 insects some of which were living in burrows made in the ground and occupied by common mice. We suspect that some of the nymphs were periodically visiting the store room of house 2 and when the original focus dissapeared this neighbor- ing store room lost its infestation. In the other two houses (14 and 25) the ecotopes were destroyed by the owners who decided on their own to follow our procedure, and this was effective in eliminating the bugs completely in these two cases. One more house (14A) was added to this group when we discovered the same response by the owners, 9 months after the start. Nevertheless, 13 months after the initial point, six houses were still infested, thereby maintaining the insect population or even increasing it (Fig. 3).

None of the selected variables mentioned before in the choice of the two groups of houses, were statistically different $(p>0.05)$. After examining the proportion of insects per house between intervened and control houses at different time intervals, we observed that control houses always had a greater proportion of insects, except at the start of the study. The differences between these two proportions were statistically significant for the first visit ( $p$ $=0.02)$, for the third visit $(\mathrm{p}=0.07)$ (if we add the three 


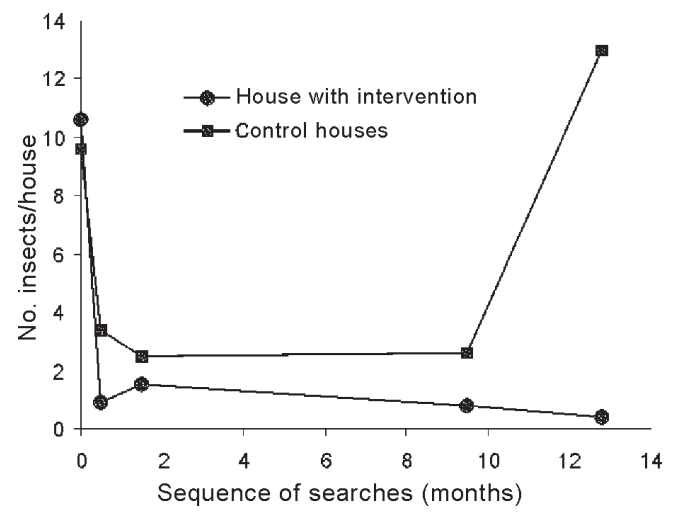

Fig. 3: mean number of insects in both houses with intervention and control houses during the 13 months of observation.

houses that were modified by the inhabitants to the intervened houses group, $\mathrm{p}=0.03)$ and for the last visit $(\mathrm{p}=$ 0.04 ). We also observed that this difference increased with time.

\section{DISCUSSION}

With a process of environmental management used as a pilot project in an area of Costa Rica where $T$. dimidiata, the main vector of Chagas disease in the country, is common, we have shown that it is possible to keep the houses free of insect colonies. In this case, the rather sound structure and sanitary conditions of the dwellings, made it difficult for the bug to thrive inside but, on the other hand, the numerous man-made ecotopes outdoors, beneath the houses or around them, provide excellent refuges for the bug and host animals. In only two cases, a few nymphs were found indoors during the first search, and these probably originated from the peridomestic colonies.

The structural improvement of houses, such as the progressive disappearance of dirt floors in areas where $T$. dimidiata exists, can be attributed to the social progress of Costa Rican rural inhabitants in the last 30-40 years. Before that, intradomicile bugs were common in certain areas of the country and a close relationship with dirt floor was evident (Zeledón et al. 1975, Zeledón \& Vargas 1984, Starr et al. 1991). In a recent study carried out in three areas of the Central Plateau and in a lowland area of the northwestern Pacific it was shown that the indoor infestation rates are much lower now than previously. Presently, outdoor colonies are more common and the number of insects is greater than in the intradomicile situation. This new behavior of $T$. dimidiata will be discussed further in another paper (Zeledón et al. unpublished data).

The area that was chosen for the pilot project, as in many other places of the country, offers numerous microhabitats for wild population of $T$. dimidiata which are frequently associated with opossum nests and from which they invade houses, either actively or passively (Zeledón 1981, Zeledón et al. 2001). This situation seems to be common in the village Barrio Pilar, where the study was performed, not only because the abundance of the marsupial but also because of the frequency with which the inhabitants noticed the arrival of adult insects to their homes.
This was reported to us by the occupants of six of the dwellings and confirmed during searches in houses 24 and 48 during the last two periods postintervention, when adult insects attempted to recolonize the modified dwellings. All insects found at that moment were in an advanced stage of starvation. In the case of house 24 a large nymph was also found during the last period and this situation, together with the loss of infestation in the cellar of house 2 (control house), could be explained by the capacity of the nymphs to walk from one place to another.

Active dispersion of nymphs and invasion of new areas was observed in T. sordida in Brazil (Forattini et al. 1979), suggested for T. dimidiata on the basis of blood source identification (Zeledón et al. 1973) and has been confirmed more recently in Guatemala for the latter insect (Monroy et al. 2003). Seasonal invasion of houses by flying adults of $T$. dimidiata, probably from sylvatic ecotopes, has been observed by Dumonteil et al. (2002) in the Yucatan Peninsula of Mexico.

It seems evident that this "ecological control" method is efficient in completely eliminating the insects or at least in considerably reducing their number by making it difficult for arriving bugs to thrive there, at least under the conditions mentioned here. Taking into consideration that the life cycle from egg to adult takes from six to 12 months (Zeledón et al. 1970a), it appears that the environmental modifications that we undertook did not allowed the production of new colonies by the small nymphs and particularly the eggs, which escaped our detection during the intervention. This is probably due to the lack of a blood source or to facilitating the action of the enemies or predators of the bugs (Zeledón et al. 1970b). In two of the modified houses we found dead females, in spider webs.

The ecological control method seems to be appropriate for those cases where the vector species is native to the area and well represented in the wild environment from which it frequently invades and colonizes human dwellings. The method has social and anthropological implications and should be applied by simultaneously educating and motivating the communities, in order to obtain full participation from all active leaders of the community.

It costs less and is more realistic than the constant use of insecticides, with all its consequences, and than physical control, with its socio-economical barriers. However, the latter, in a long-term perspective, is the ideal solution for a better and permanent control.

Bos (1988) after emphasizing the theoretical importance of this type of approach for the control of peridomestic populations of triatomines, discussed some of the inconveniences of using insecticide spraying in these cases. Wisnivesky-Colli (1993) makes reference to the serious barriers to chemical control in the peripheral areas and housing annexes, in an area of Argentina; she considered it to be an ineffective tool for the control of peridomestic bugs which, in the case of $T$. infestans, are responsible for the recolonization of human dwellings after eliminating intradomiciliary infestations. Diotaiuti et al. (1998) made similar remarks in relation to the problem of peridomiciliary infestation by T. sordida and Panstrongylus megistus and their domiciliation in central Brazil. Silveira et al. (2001) pointed out the same problem in the case of $T$. brasiliensis 
and T. pseudomaculata, also in Brazil, where chemical control has not been very effective, due to their persistence in the peridomicile and in wild habitats from where they can again invade the interior of the houses.

Chemical control of domiciliated T. dimidiata in Honduras was not satisfactory 6 months after the intervention (Oliveira Filho 1997). In Nicaragua, insecticide spraying was effective in lowering bug populations for up to 12 months of observation but in Guatemala it was noticed that the domiciliary infestation, after suffering a reduction, progressively recuperates apparently at the expense of outside foci which are responsible for the intradomicile reinfestation (Acevedo et al 2000, Cordón-Rosales 2002). Dumonteil et al. (2002) in the Yucatan Peninsula of Mexico, observed a seasonal migration of $T$. dimidiata adults to the houses, possibly from sylvatic ecotopes. In four houses sprayed with cyfluthrin, reinfestation by adult insects, four months later, also became evident (Dumonteil et al. 2004).

A comparison of pyrethroid insecticide effectiveness, after spraying them with manual or motor sprayers against peridomestic T. infestans in rural western Argentina, came to the conclusion that the insecticides "failed to eliminate T. infestans in peridomestic sites just 1-year post-spraying" (Gürtler et al. 2004). Rojas-Wastarino (2004) also compared two modalities of insecticide spraying with hygienic measures carried out by the inhabitants and observed that the former were more effective in controlling domestic $T$. dimidiata infestation than the cleaning program. They concluded that the latter method, which included the removing of accumulated elements and physical improvements of the dwellings, failed in some cases due to the reluctance of the inhabitants in following instructions.

From all these facts, we can infer that the characteristics of the peridomiciles in many geographical areas of Latin America offer excellent refuges for domestic and synanthropic mammals allowing the formation of colonies of triatomines that are hard to eliminate by conventional methods. Insecticides are easily degraded in these environments and the insects have mechanisms of escaping their action. For these reasons, peridomiciles, as sources of intradomicile reinfestations, are real threats and a challenge for control campaigns that will have to face new modalities of actions.

The ecological control method that we present here shows characteristics of being an economic and sustainable mechanism to make it difficult for the bugs to thrive, by modifying or destroying man-made artificial ecotopes in or outside dwellings. The method is based on the knowledge we have of the biology and behavior of these insects and seeks the motivation and participation of the individuals of each community involved. This method is aimed to be effective particularly in areas where a given species of insect is well represented in sylvatic ecotopes and have a tendency to invade and colonize the peridomicile of the households.

\section{ACKNOWLEDGEMENTS}

To Mrs Carmen Flores, Mr Carlos Picado, Miss Yahaira Rojas, Miss Miriam Tejada, and Miss Eylen Zuñiga for their dedicated field work and technical assistance. To the commu- nity members of Vuelta de Jorco village for their full collaboration, in particular to the leader, Mr Carlos E Fallas, for his invaluable participation in the different phases of the project. To Dr Paul Hanson from the School of Biology of the University of Costa Rica, for reviewing the manuscript and for helpful comments. Mr Roberto Castro, helped us in the statistical analysis of the data.

\section{REFERENCES}

Acevedo F, Godoy E, Schofield CJ 2000. Comparison of intervention strategies for control of Triatoma dimidiata in Nicaragua. Mem Ins. Oswaldo Cruz 95: 867-871.

Bos R 1988. The importance of peridomestic enviromental management for the control of the vectors of Chagas disease. Rev Argentina Microbiol 20: 58-62.

Cordón-Rosales C 2002. Investigación operativa sobre los triatomineos vectores de la Enfermedad de Chagas en Guatemala. In Taller para el Establecimiento de Pautas Técnicas en el Control de Triatoma dimidiata, OPS/ OMS, OPS/HCP/ HCT/214/02, San Salvador, El Salvador, p. 20-22.

Diotaiuti L, Azeredo BVM, Busek SCU, Fernandes AJ 1998. Control do Triatoma sordida no peridomicilio rural do municipio de Porteirinha, Minas Gerais, Brasil. Rev Panam Sal Publ 3: 21-25.

Dumonteil E, Gourbiere S, Barrera-Pérez M, Rodríguez-Félix E, Ruíz-Piña H, Boños-Lopez O, Ramírez-Sierra MJ, Menu F, Rabinovich JE 2002. Geographic distribution of Triatoma dimidiata and transmission dynamics of Trypanosoma cruzi in the Yucatan Peninsula of Mexico. Am J Trop Med Hyg 67: 176-183.

Dumonteil E, Ruiz-Piña H, Rodriguez-Felix E, Barrera-Perez M, Ramírez-Sierra MJ, Rabinovich JE, Menu F 2004. Reinfestation of houses by Triatoma dimidiata after intradomicile insecticide application in the Yucatan Peninsula, Mexico. Mem Inst Oswaldo Cruz 99: 253-256.

Forattini OP, Ferreira OA, Rocha e Silva EO da, Robello EX 1979. Aspectos ecológicos da tripanossomíase americana. XV. Desenvolvimento, variação e permanência de Triatoma sordida, Panstrongylus megistus e Rhodnius neglectus en ecótopos artificiais. Rev Saúde Públ São Paulo 13: 220234.

Gürtler RE, Canale DM, Spillmann C, Stariolo R, Salomón OD, Blanco S, Segura EL 2004. Effectiveness of residual spraying of peridomestic ecotopes with deltametrin and permethrin on Triatoma infestans in rural western Argentina: a district-wide randomized trail. Bull WHO 82: 196205.

Monroy MC, Bustamante DM, Rodas AG, Enríquez ME, Rosales RG 2003. Habitats, dispersion and invasion of sylvatic Triatoma dimidiata (Hemiptera: Reduviidae: Triatominae) in Petén, Guatemala. J Med Entomol 40: 800806.

Oliveira Filho AM 1997. Uso de nuevas herramientas para el control de triatómineos en diferentes situaciones entomológicas en el Continente Americano. Rev Soc Brasil Med Trop 30: 41-46.

OPS-Organización Panamericana de la Salud 2002. Taller para el Establecimiento de Pautas Técnicas en el Control de Triatoma dimidiata, San Salvador, El Salvador. 11-13 marzo 2002. OPS/ HCP/ HCT/ 214/ 02, 36 pp.

Ponce C 1996. La enfermedad de Chagas en Centroamérica. In 
CJ Schofield, JP Dujardin, J Jurberg (eds), Proc. Intl. Worshop Pop. Genet. \& Control Triatominae, Santo Domingo de los Colorados, Ecuador, INDRE, Mexico City, p. 41.

Rojas-Wastarino G, Cabrera-Bravo M, García-De La Torre G, Vences-Blanco M, Ruiz-Hernández A, Bucio-Torres M, Guevara-Gómez Y, Escobar-Mesa A, Salazar-Schettino PM 2004. Insecticide and community interventions to control Triatoma dimidiata in locations of the State of Veracruz, Mexico. Mem Inst Oswaldo Cruz 99: 433-437.

Silveira AC, Vinhaes MC, Lira E, Araujo E 2001. O Controle de Triatoma brasiliensis e Triatoma pseudomaculala II, Organizaçião Pan-Americana da Saúde, Brasília, 60 pp.

Snedecor GW, Cochram WG 1989. Statistical Methods, 8th ed., The Iowa State University Press, Ames-Iowa, 503 pp.

Starr MD, Rojas JC, Zeledón R, Hird DW, Carpenter TE 1991. Chagas' disease: risk factors for house infestation by Triatoma dimidiata, the major vector of Trypanosoma cruzi in Costa Rica. Am J Epidemiol 133: 740-747.

WHO-World Health Organization 2002. Control of Chagas Disease, Second Report of the WHO Expert Committee, WHO Technical Report Series 905, 109 pp.

Wisnivesky-Colli C 1993. La importancia del peridomicilio en un programa de eliminación de Triatoma infestans. Rev Soc Brasil Med Trop 26 (Supl. III): 55-63.

Zeledón R 1981. El Triatoma dimidiata (Latreille, 1811) y su relación con la Enfermedad de Chagas, Editorial Universi- dad Estatal a Distancia, San José, Costa Rica, 146 pp.

Zeledón R 1996. Enfermedad de Chagas en Centroamérica. In CJ Schofield, JP Dujardin, J Jurberg (eds.), Proc. Intl. Worshop. Pop. Genet. \& Control Triatominae, Santo Domingo de los Colorados, Ecuador, INDRE, Mexico City, p. 40.

Zeledón R, Vargas LG 1984. The role of dirt floors and of firewood in rural dwellings in the epidemiology of Chagas disease in Costa Rica. Am J Trop Med Hyg 33: 232-235.

Zeledón R, Guardia VM, Zúñiga A, Swartzwelder JC 1970a. Biology and ethology of Triatoma dimidiata (Latreille, 1811). I. Life cycle, amount of blood ingested, resistance to starvation, and size of adults. J Med Entomol 7: 313-319.

Zeledón R, Solano G, Burstin L, Swartzwelder JC 1975. Epidemiological pattern of Chagas disease in an endemic area of Costa Rica. Am J Trop Med Hyg 24: 214-225.

Zeledón R, Solano G, Zúñiga A, Swartzwelder JC 1973. Biology and ethology of Triatoma dimidiata (Latreille, 1811). III. Habitat and blood sources. J Med Entomol 10: 363370.Zeledón R, Ugalde JA, Paniagua LA 2001. Entomological and ecological aspects of six sylvatic species of triatomines (Hemiptera, Reduviidae) from the collection of the National Biodiversity Institute of Costa Rica, Central America. Mem Inst Oswaldo Cruz, 96: 757-764.

Zeledón R, Valerio CE, Valerio JE 1970b. Enemies of Triatoma dimidiata (Latreille, 1811) in an endemic area of Chagas disease in Costa Rica (Hemiptera, Reduviidae). J Med Entomol 7: 722-724. 